\title{
CROWDFUNDING SEBAGAI AKSES ALTERNATIF PERMODALAN BERBASIS TEKNOLOGI DIGITAL PADA KEGIATAN PERTANIAN (Studi Kasus di PT Crowde Membangun Bangsa)
}

\section{CROWDFUNDING AS ALTERNATIVE ACCESS TO DIGITAL TECHNOLOGY- BASED CAPITAL ON AGRICULTURAL ACTIVITIES (Case Study at PT Crowde Membangun Bangsa)}

\author{
Astari Avisha*, Anne Charina, Trisna Insan Noor, Gema Wibawa Mukti \\ Universitas Padjadjaran, Jln. Raya Bandung-Sumedang Km. 21 \\ *Corresponding email: *astariavisha.aa@gmail.com \\ (Diterima 25-08-2018; Disetujui 26-12-2018)
}

\begin{abstract}
ABSTRAK
Saat ini perkembangan industri jasa keuangan dengan sentuhan inovasi teknologi atau disebut financial technology (Fintech) mulai merambah ke sektor pertanian, bahkan pemanfaatannya digunakan untuk menggarap skala usaha di tingkat petani. Salah satu bentuk implementasi Fintech pada sektor pertanian yaitu crowdfunding yang merupakan sebuah aktivitas penggalangan dana untuk permodalan petani secara daring (online) menggunakan media digital (internet). Salah satu platform crowdfunding di Indonesia yang bergerak di bidang pertanian adalah Crowde. Penelitian ini bertujuan untuk mengetahui deskripsi konsep manajemen crowdfunding yang dilakukan oleh Crowde sebagai akses alternatif permodalan berbasis teknologi digital pada kegiatan pertanian serta mengetahui respon petani mitra terhadap konsep crowdfunding yang dilakukan oleh Crowde. Teknik penelitian yang digunakan adalah studi kasus dengan desain kualitatif deskriptif menggunakan pendekatan Model Milles dan Huberman. Hasil penelitian menunjukkan bahwa pada tahap perencanaan, Crowde melakukan profiling petani dan analisis proyek, serta menetapkan adanya biaya provisi. Sedangkan tahap pelaksanaan crowdfunding meliputi penggalangan dana di website, penyaluran modal melalui toko tani dan pengembalian dana pemodal melalui fitur Wallet. Sementara tahap pengawasan berlangsung selama proyek berjalan melalui pemantauan dan sistem pelaporan proyek. Petani mitra Crowde menunjukan respon yang positif terhadap skema crowdfunding sebagai akses permodalan. Sebagian besar petani mitra mengatakan proses atau prosedur dari skema permodalan tersebut sangat mudah diikuti dan menilai bahwa model crowdfunding ini sangat bermanfaat dan cocok sebagai akses permodalan petani.
\end{abstract}

Kata Kunci: Crowdfunding, Permodalan Petani, Manajemen, Respon

\begin{abstract}
Currently the development of the financial services industry with a touch of technological innovation or called financial technology (Fintech) began to penetrate into the agricultural sector, even utilization is used to work on the scale of business at the farm level. One form of Fintech implementation in the agricultural sector is crowdfunding which is a fund raising activity for farmers capital by online using digital media (internet). One of the crowdfunding platforms in Indonesia which is engaged in agriculture is Crowde. This study aims to find out the description of crowdfunding management concepts conducted by Crowde as access to alternative capital based on digital technology on agricultural activities and to know the response of farmers partners to the concept of crowdfunding conducted by Crowde. The research technique used is case study with descriptive qualitative design using Milles Model and Huberman approach. The results show that during the planning phase, Crowde conducts farmer profilling and project analysis, and establishes provision fees. While the implementation stage of crowdfunding involves raising funds on the website, channeling capital through a farm shop and refunding investors through the Wallet
\end{abstract}


feature. While the controlling phase takes place during the project through the project monitoring and reporting system. Crowde partner farmers showed a positive response to the crowdfunding scheme as access to capital. Most of the partner farmers say the process or procedure of the capital scheme is very easy to follow and judge that the crowdfunding model is very useful and suitable as access to farmers' capital.

Keywords: Crowdfunding, Farmers Capital, Management, Response

\section{PENDAHULUAN}

Pesatnya perkembangan teknologi informasi dan digital saat ini menjadi latar belakang penggunaan internet dan media digital di Indonesia yang semakin meluas. Hasil survei yang dilakukan oleh Asosiasi Penyelenggara Jasa Internet Indonesia (APJI) menyebutkan bahwa pengguna internet di Indonesia hingga akhir tahun 2016 mencapai 132,7 juta orang. Hal ini meningkat jika dibandingkan dengan tahun 2014, pengguna internet di Indonesia sebanyak 88 juta orang. Data tersebut semakin membuktikan bahwa masyarakat Indonesia sudah semakin lekat dengan penggunaan teknologi internet.

Sejalan dengan perkembangan teknologi informasi dan digital, saat ini di Indonesia tengah berkembang industri jasa keuangan dengan sentuhan inovasi teknologi atau disebut financial technology (Fintech). Fintech mengacu pada penggunaan teknologi untuk memberikan solusi keuangan dengan memanfaatkan teknologi software, internet, komunikasi, dan komputasi terkini (Arner et al, 2015).

\section{National Digital Research Centre}

di Dublin, Irlandia mendefinisikan Fintech sebagai innovation in financial services atau inovasi dalam layanan keuangan. Fintech bertujuan untuk memudahkan masyarakat dalam mengakses produk-produk keuangan, mempermudah transaksi dan juga meningkatkan literasi keuangan. Hal ini dapat dilihat dari data yang dicatat oleh Otoritas Jasa Keuangan (OJK) tentang meningkatnya transaksi yang menggunakan teknologi selama tahun 2015 mencapai USD 590 miliar, tumbuh 10\% dibandingkan 2014.

Menurut Otoritas Jasa Keuangan, munculnya Fintech merupakan dorongan dari sebuah fenomena inovasi disruptif yang terjadi di Industri Jasa Keuangan. Otoritas Jasa Keuangan menyebutkan alasan-alasan yang menyebabkan mengapa Fintech dapat berkembang dengan pesat yakni masyarakat tidak dapat dilayani oleh industri keuangan tradisional. Hal ini terkait dengan 
perbankan masih terikat aturan yang ketat dan keterbatasan industri perbankan dalam melayani masyarakat di daerah tertentu. Oleh karena itu, masyarakat mencari alternatif pendanaan dan pembiayaan yang lebih transparan. Hal tersebut juga ditambah dengan Fintech menerapkan biaya layanan keuangan yang efisien dan dapat menjangkau masyarakat luas.

Fintech terbagi berdasarkan beberapa bentuk dasar, yakni sektor keuangan (perbankan, investasi, asuransi, dan lain-lain), proses bisnis yang dialaminya (pembayaran, investasi, perdagangan, infrastruktur dan lain-lain), segmen konsumen (eceran atau perusahaan), atau berdasarkan bentuk interaksinya (business to business, business to costumer, costumer to costumer) (Alt, R., \& Puschmann, T., 2012). Sedangkan menurut Nofie Iman dalam presentasinya pada tahun 2016 menerangkan bahwa bentuk dasar fintech terdiri atas proses bisnis yang meliputi pembayaran (digital wallets, peer-to-peer payments), investasi (equity Crowdfunding, peer-to-peer lending), pembiayaan (Crowdfunding, micro-loans, credit facilities), asuransi (risk management), lintas-proses (big data analysis, predictive modeling), infrastruktur (security).

Fintech kini telah merambah ke sektor pertanian yang pemanfaatannya digunakan untuk pembiayaan usaha di tingkat petani. Implementasi Fintech pada sektor pertanian melalui salah satu bentuknya yaitu crowdfunding sebagai model pembiayaan usahatani atau proyek pertanian. Crowdfunding merupakan sebuah aktivitas penggalangan dana yang dilakukan oleh individu atau kelompok wirausaha untuk mendanai usaha mereka yang berasal dari kontribusi yang relatif kecil dari sejumlah besar individu melalui internet, tanpa adanya standar keuangan tertentu (Mollick, 2014).

Model pembiayaan ini merupakan model baru dalam dunia pertanian. Skema-skema yang terdapat pada model pembiayaan ini harus terus dikembangkan agar kesempatan petani untuk mendapatkan akses permodalan kian mudah dan cepat. Beberapa pelaku Fintech di Indonesia yang bergerak pada sektor pembiayaan pertanian diantaranya Growpal, Sawah Kita, dan Crowde, Iwak.Me, iGrow, dan Eragano.

Petani yang memiliki keterbatasan modal serta sulit untuk mengakses kredit ke lembaga keuangan berpeluang untuk dapat memanfaatkan teknologi digital 


\section{CROWDFUNDING SEBAGAI AKSES ALTERNATIF PERMODALAN \\ BERBASIS TEKNOLOGI DIGITAL PADA KEGIATAN PERTANIAN \\ Astari Avisha, Anne Charina, Trisna Insan Noor, Gema Wibawa Mukti}

dengan konsep crowdfunding sebagai akses alternatif permodalan untuk mengusahakan kegiatan usahataninya. Bagaimanapun modal masih merupakan kendala utama bagi sebagian besar petani selain kendala-kendala lainnya seperti teknologi, informasi pasar dan perubahan iklim, terutama bagi petani dengan skala usaha yang kecil. Sedangkan modal adalah salah satu faktor internal yang penting dalam pelaksanaan usahatani yang dijalankan oleh petani (Soetriono, 2006). Petani skala kecil atau disebut juga petani gurem memperoleh modal biasanya dari penyisihan pendapatan usahatani sebelumnya. Dengan kondisi yang masih menghadapi risk of uncertainty, maka petani berada pada posisi yang kurang menguntungkan, ditambah beban kebutuhan keluarga sehari-hari. Keadaan ini yang lantas menyebabkan petani dapat terjerat dengan sistem pinjaman yang merugikan. Tidak jarang petani melakukan peminjaman modal usahatani ke berbagai tempat.

Peminjaman modal usahatani biasanya dilakukan ke lembaga keuangan formal (bank, koperasi simpan pinjam, kelompok tani, dan KUD) ataupun nonformal (rentenir, bank titil). Adapun pada segi permodalan, petani seringkali merasa kesulitan dalam mengakses modal ke lembaga keuangan. Selain itu ditambah dengan adanya persepsi negatif petani terhadap lembaga keuangan, seperti misalnya petani masih menganggap proses yang ada pada lembaga keuangan formal adalah sulit dan mahal, petani masih minim informasi yang mendalam mengenai lembaga keuangan formal dan petani beranggapan sistem bunga akan menjerat mereka (Supanggih, et al., 2013).

Hal itulah yang menjadi latar belakang munculnya konsep crowdfunding yang dapat dijadikan akses alternatif terhadap permodalan kegiatan pertanian. Sejalan dengan hal tersebut, maka muncul berbagai platform crowdfunding di Indonesia yang memfasilitasi proyek atau kegiatan pertanian untuk mendapatkan bantuan modal melalui media digital.

Salah satu platform crowdfunding di Indonesia yang bergerak khusus di bidang pertanian adalah Crowde. PT. Crowde Membangun Bangsa (Crowde) melalui situs www.crowde.com merupakan portal crowdfunding terintegrasi Indonesia yang telah berdiri sejak September 2015 dan saat ini telah resmi terdaftar serta diawasi oleh Otoritas Jasa Keuangan sebagai Penyelenggara 
Layanan Pinjam Meminjam Uang Berbasis Teknologi Informasi.

Crowde menilai sistem peminjaman dari bank di Indonesia saat ini dirasa masih sulit diakses oleh para petani. Selain itu, menurunnya kualitas hidup para petani karena tidak bisa menikmati hasil kerja keras mereka secara utuh akibat besarnya bunga pinjaman menjadi latar belakang Crowde mempunyai misi untuk memberikan dampak positif kepada para petani dan masyarakat Indonesia secara luas dengan menjadi platform terbuka bagi masyarakat untuk berinvestasi dengan cara memberi modal kepada para petani. Crowde memiliki harapan yakni dapat hadir sebagai solusi untuk permasalahan di bidang agraria. Crowde juga bahkan mengklaim dapat memberi kesempatan berinvestasi yang menguntungkan bagi Teman Crowde, yakni para pemodal, maupun petani dengan sistem bagi hasil setelah panen, sesuai dengan persentase modal investasi yang diberikan.

Jumlah petani yang telah bekerjasama dengan Crowde hingga saat ini telah mencapai lebih dari 5.071 petani yang tersebar di 276 desa di Indonesia. Bentuk proyek pertanian yang didanai juga beragam seperti budidaya tanaman, perdagangan komoditas, pembelian bibit, pengiriman permintaan pasokan komoditas, industri pengolahan makanan, dan lain sebagainya. Jenis proyek pertanian yang dapat mengajukan permodalan tak hanya pada kegiatan pertanian dalam arti sempit, melainkan pertanian secara luas, meliputi perikanan, peternakan, dan juga perkebunan.

Berdasarkan uraian di atas, dapat diperoleh gambaran bahwa Crowde merupakan salah satu platform yang menggunakan teknologi finansial dengan mengusung konsep crowdfunding sebagai alternatif permodalan yang dapat diakses oleh petani dengan menggunakan media digital. Sementara itu, manajemen dalam menjalankan konsep crowdfunding yang diusung oleh Crowde sangat dibutuhkan sebagai upaya untuk mencapai tujuan dari pelaksanan konsep tersebut. Sehubungan dengan hal itu, maka penulis tertarik untuk mengetahui bagaimana konsep manajemen crowdfunding yang diusung oleh Crowde dan bagaimana respon petani. Dengan demikian, penelitian ini akan membahas mengenai crowdfunding sebagai akses alternatif terhadap permodalan berbasis teknologi digital pada kegiatan pertanian dengan melakukan studi kasus di PT Crowde Membangun Bangsa. 


\section{METODE PENELITIAN}

Objek yang diteliti dalam penelitian ini yaitu konsep manajemen crowfunding yang diterapkan oleh Crowde dan respon petani dan mitra terhadap konsep crowdfunding Crowde. Tempat penelitian dilakukan di PT Crowde Membangun Bangsa yang berlokasi di Jalan Bandengan Selatan No. 58 C, Penjaringan, Jakarta. Penelitian ini menggunakan desain kualitatif deskriptif untuk mengkaji bagaimana crowdfunding sebagai akses alternatif permodalan berbasis teknologi pada kegiatan pertanian. Adapun teknik penelitian yang digunakan adalah studi kasus atau penelitian kasus (case study). Sumber data yang digunakan meliputi data primer dan data sekunder dimana dilakukan pengamatan langsung (observasi), wawancara, dan dokumentasi. Pengumpulan data primer yakni melalui teknik wawancara kepada para informan kunci yang ditentukan secara sengaja (purposive), terdiri atas 5 orang yang berasal dari pihak Crowde dan 5 orang yang terdiri atas pihak petani dan mitra Crowde yang berada di Provinsi Jawa Barat. Untuk menganalisis data dalam peneltian ini, penulis merujuk pada langkah-langkah analisis deskriptif dengan pendekatan Model Milles dan
Huberman dalam Sugiyono (2012) yang terdiri atas reduksi data (Data Reduction), penyajian data (Data Display), dan penarikan kesimpulan/ verifikasi (Conclusion Drawing/ Verification).

\section{HASIL DAN PEMBAHASAN}

\section{Manajemen pada Sistem Crowdfunding PT. Crowde Membangun Bangsa}

Dari hasil penelitian yang diperoleh di lapangan, berikut akan dibahas bagaimana proses manajemen model crowdfunding untuk permodalan petani yang dilakukan oleh Crowde menggunakan teori yang dikemukakan oleh George R. Terry dalam Siswanto (2006) mengenai fungsi manajemen yaitu perencanaan (planning), pengorganisasian (organizing), pelaksanaan (actuating), dan pengawasan (controlling). Tahapan pelaksanaan fungsi manajemen pada model crowdfunding yang dilakukan oleh Crowde dijelaskan sebagai berikut:

\subsection{Perencanaan (Planning)}

Perencanaan atau Planning merupakan proses manajemen yang pertama. Menurut Koontz (2010), perencanaan adalah fungsi manajemen yang berhubungan dengan penetapan tujuan-tujuan, kebijakan-kebijakan, 
prosedur-prosedur, program-program dari beberapa alternatif yang ada. Pembahasan mengenai tahapan yang terdapat dalam perencanaan yang dilakukan oleh Crowde merujuk pada tahapan dalam kegiatan perencanaan menurut Handoko (2000).

\section{a. Penetapan tujuan atau serangkaian tujuan}

Tahapan yang pertama ini mencakup perumusan tentang serangkaian keinginan yang menjadi tujuan dari sebuah organisasi. Tanpa rumusan tujuan yang jelas, sebuah organisasi akan menggunakan sumber dayanya secara tidak efektif. Selain itu, dengan menetapkan tujuan maka akan memberikan arah pada organisasi dalam penentuan kebutuhan dan kebijakan. Seperti halnya pada Crowde yang dari awal terbentuknya memiliki tujuan, baik tujuan perusahaan secara umum dan tujuan mengenai pelaksanaan sistem crowdfunding secara khusus.

Tujuan Crowde seperti yang diungkapkan oleh Yohannes selaku Chief Executive Officer adalah ingin membantu petani untuk benar-benar mendapat kehidupan yang lebih baik. Dari sekian banyak masalah yang dimiliki petani, Crowde baru berupaya untuk mengatasi masalah pembiayaan (financing), dengan bagaimana caranya memberikan petani akses permodalan yang lebih baik. Walaupun sekarang sudah banyak pihak-pihak yang mengatasi hal yang sama. Menurutnya Crowde berfokus pada kebutuhan petani dan benar-benar memberikan sesuai dengan apa yang diinginkan dan dibutuhkan petani.

Adapun tujuan secara khusus dari crowdfunding yang dilakukan oleh Crowde sebagai berikut: a) membuat ekosistem yang efisien untuk mendukung para petani dan semua stakeholder di pertanian; b) membuat petani menjadi lebih mandiri dengan membuat petani menjadi agropreneur; c) menjadi satu-satunya platform yang menjadi pilihan untuk akses finansial bagi para petani dan juga para pemodal yang ingin berinteraksi dengan petani.

\section{b. Perumusan keadaan saat ini}

$$
\text { Selain merumuskan dan }
$$
menetapkan tujuan yang ingin dicapai, dalam perencanaan juga sangat penting untuk memahami kondisi saat ini, baik pada organisasi atau perusahaan, karena tujuan tersebut menyangkut waktu yang akan datang. Tentu saja, untuk mencapai model bisnis yang menguntungkan, sebuah crowdfunding platform (CFP) harus menemukan cara untuk mendapatkan bagian (keuntungan) dari 


\section{CROWDFUNDING SEBAGAI AKSES ALTERNATIF PERMODALAN \\ BERBASIS TEKNOLOGI DIGITAL PADA KEGIATAN PERTANIAN \\ Astari Avisha, Anne Charina, Trisna Insan Noor, Gema Wibawa Mukti}

nilai yang mereka miliki untuk penggunanya. Dari setiap proyek bagi hasil petani yang terpenuhi pendanaannya melalui website, pihak Crowde menetapkan biaya provisi sebesar 3\% dari dana pemodal yang terkumpul dan akan langsung terpotong sebelum dilakukan pencairan dana kepada petani. Penetapan biaya ini ternyata serupa dengan pendapat yang dikemukakan oleh Belleflamme dkk (2016) mengenai strategi yang dapat diterapkan oleh CFP salah satunya melalui strategi menetapkan harga. Saat ini, sebagian besar biaya CFP menerapkan "pajak" pada transaksi yang sukses. Praktik secara umumnya adalah membebankan biaya transaksi untuk penggalangan dana bagi semua proyek yang sukses (terdanai) sementara proyek yang gagal terdanai umumnya tidak dikenai pajak.

\section{c. Mengembangkan rencana atau serangkaian kegiatan untuk pencapaian tujuan}

Tahap akhir dalam proses perencanaan adalah pengembangan berbagai alternatif kegiatan untuk pencapaian tujuan yang keluarannya (output) berupa aktivitas yang dilakukan sebelum memasuki proses bisnis yang utama Crowde yaitu crowdfunding yang disajikan melalui pembahasan sebagai berikut:

1) Penetapan syarat dan ketentuan serta hak dan kewajiban bagi petani dan pemodal

Terdapat ketentuan tidak langsung bagi petani yang mengajukan permodalan, yaitu harus mau atau sudah fasih menggunakan komunikasi digital karena menyangkut sistem yang diterapkan oleh Crowde. Hal yang paling sederhana dari penggunaan komunikasi digital tersebut yaitu petani setidaknya dapat menggunakan sarana komunikasi yang mempunyai fitur-fitur komunikasi secara langsung (real time) termasuk juga di dalamnya dapat mengirim gambar atau foto. Hal ini berhubungan dengan keterbatasan tim Crowde dalam menjangkau petani secara langsung dalam rangka pemantauan proyek, dimana dalam permodalan model crowdfunding ini petani harus memberikan laporan terkait perkembangan proyek yang sedang berjalan secara berkala. Selain itu, Crowde memiliki kebijakan bahwa hanya mendanai petani yang memiliki akun atau rekening bank. Hal ini dimaksudkan guna mengarahkan petani dalam segi literasi keuangan.

Selain syarat dan ketentuan yang harus dipenuhi oleh petani, terdapat pula hak dan kewajiban bagi petani dalam 
bekerjasama dengan pihak Crowde untuk mengajukan permodalan. Hak petani meliputi: a) mendapatkan penyaluran dana permodalan dari pihak Crowde, b) memiliki hak untuk melakukan perluasan kegiatan proyek setelah disepakati oleh pihak Crowde, c) mendapatkan pembagian hasil kerjasama yang telah disepakati dengan pihak Crowde. Kewajiban petani meliputi: a) memastikan bahwa kegiatan proyek berjalan dengan baik, b) bertanggungjawab untuk mengawasi jalannya kegiatan proyek dan bertanggungjawab jika kegiatan proyek mengalami kendala, c) memberikan laporan dengan detail jika kegiatan proyek mengalami kendala, d) berjanji untuk melakukan pengembalian kepada pihak Crowde berupa dana permodalan beserta pengembalian bagi hasil (skema bagi hasil) atau imbal hasil/return (skema pinjaman) sesuai dengan waktu yang disepakati. Jika mengalami hambatan, petani berjanji untuk paling tidak mengembalikan pengembalian imbal hasil untuk dipertanggungjawabkan terlebih dahulu kepada pihak Crowde dan pemodal.

Sementara itu syarat dan ketentuan bagi pemodal Crowde ${ }^{1}$ diantaranya:

\footnotetext{
${ }^{1}$ Andrew Tobing, Head of Operations Crowde
}

a) pemodal (investor) wajib mengisi data diri dengan benar, seperti nama, alamat, nomor rekening serta informasi lainnya,

b) transaksi dana permodalan oleh pemodal harus dilakukan selama $1 \mathrm{x}$ 24 jam setelah check out. Jika pemodal tidak melakukan transaksi pada jangka waktu tersebut, maka permodalan akan dibatalkan,

c) pemodal tidak dapat memindahkan, menukar dan/atau menarik dana permodalan dari proyek permodalan yang telah dikonfirmasi transaksinya. Namun, jika proyek permodalan tidak sesuai dengan waktu yang seharusnya maka pemodal dapat melakukan pembatalan permodalan.

d) beberapa hal yang harus diketahui dan disetujui oleh pemodal sebelum melakukan permodalan yaitu pemodal menyetujui bahwa ada risiko keterlambatan pengembalian dana permodalan pada proyek pinjaman serta menyetujui semua risiko yang terdapat pada proyek dengan skema bagi hasil,

e) pemodal wajib mengirimkan dana permodalan menggunakan nomor rekening yang terdaftar di akun user (pemodal), serta menggunakan kode 


\section{CROWDFUNDING SEBAGAI AKSES ALTERNATIF PERMODALAN \\ BERBASIS TEKNOLOGI DIGITAL PADA KEGIATAN PERTANIAN \\ Astari Avisha, Anne Charina, Trisna Insan Noor, Gema Wibawa Mukti}

unik transaksi yang diberikan oleh CROWDE.

Sedangkan para pemodal Crowde memiliki hak sebagai berikut:

a) mendapatkan pengembalian dana permodalan ditambah dengan profit yang telah didapatkan, baik melebihi ataupun kurang, dari ekspektasi profit yang telah diproyeksikan setelah proyek terkait dinyatakan selesai.

b) mendapatkan laporan mengenai proyek permodalan yang sedang dimodali serta laporan penjualan komoditi ketika proyek permodalan telah berakhir.

\section{2) Profiling petani}

\section{Pengisian formulir pendaftaran (tahap administrasi)}

Setiap petani yang ingin mengajukan permodalan akan diberikan sebuah formulir pendaftaran yang harus diisi oleh petani. Formulir tersebut berisi informasi detil mengenai identitas diri petani serta alasan ingin menjadi mitra Crowde. Untuk pengembalian formulir petani juga diwajibkan untuk melampirkan foto-foto seperti foto kartu tanda penduduk, foto kartu keluarga, foto rumah, foto surat keterangan usaha, foto wajah dengan KTP, serta foto untuk profil di website.

\section{Credit scoring}

Credit scoring merupakan langkahlangkah yang digunakan untuk memperkecil kemungkinan adanya upaya penipuan dari petani melalui analisa pengukuran kelayakan baik pada usahatani atau proyek maupun petani yang mengajukan permodalan. Pengukuran ini mulai dilakukan sejak petani melakukan pengajuan permodalan. Adapun parameter petani yang dapat mengajukan permodalan tidak hanya berdasarkan kemampuan petani dalam melakukan pengajuan, melainkan juga berdasarkan faktor-faktor lain seperti berapa lama petani mengisi form pengajuan, dimana melalui hal tersebut dapat dilihat motivasi petani tersebut.

Pada credit scoring ini dilakukan penilaian atau assessment terhadap petani. Bentuk penilaian yang dilakukan oleh Crowde yaitu dengan menghubungi langsung petani untuk ditanyakan seputar kehidupan pribadi dan mengenai hal-hal yang petani tulis di formulir pengajuan. Selain penilaian terhadap diri petani, Crowde juga memiliki tahap penilaian infrastructure. Tahap ini bertujuan untuk menilai bagaimana kualitas petani dan memastikan apakah petani tersebut dapat diandalkan. Namun penilaian tersebut bukan dari petani itu sendiri melainkan 
dari lingkungannya (environment) ${ }^{2}$ seperti dimana letak toko tani yang terdekat, siapa yang akan mengambil hasil panennya (pasar), dimana Crowde dalam hal ini ingin mengetahui dari hulu ke hilir ekosistem yang dimiliki petani tanpa harus mengaturnya sehingga petani dapat berkembang secara mandiri. Selain itu, penilaian pada tahap ini juga bertujuan untuk mengetahui seberapa jauh petani dapat menjamin dana dari pemodal dan seberapa jauh petani dapat bekerjasama dengan Crowde melalui persyaratan yang ada.

\section{3) Project Analysis}

Selain analisis terhadap petani melalui profiling petani, setiap proyek yang akan diajukan permodalannya oleh petani juga akan dilakukan analisis oleh Crowde. Analisis proyek ini berupa penilaian kelayakan usaha yang akan dijalankan oleh petani. Analisis dilakukan dengan melihat rencana usaha (proyek) pertanian yang terdapat pada formulir pengajuan kerjasama usaha pertanian yang diajukan oleh petani. Formulir pengajuan tersebut memberikan gambaran tentang perencanaan komoditas yang akan diusahakan atau dibudidayakan, rencana pembelanjaan

\footnotetext{
${ }^{2}$ Andrew Tobing, Head of Operations Crowde
}

sarana produksi, serta perkiraan penerimaan pendapatan.

\subsection{Pengorganisasian (Organizing)}

Pengorganisasian merupakan pembagian kerja bagi berbagai potensi yang ada untuk bekerjasama agar tujuan yang telah ditetapkan dapat tercapai. Pengorganisasian memiliki manfaat penting dalam proses manajemen, sebab melalui pengorganisasian akan dapat diketahui dengan jelas pembagian tugas untuk perorangan atau kelompok dan bagaimana hubungan antar orang-orang di dalam perusahaan melalui kegiatan yang dilakukannya. Pengorganisasian mencakup pengaturan struktur organisasi, susunan personalia serta hak dan wewenang dari setiap tenaga pelaksana sedemikian rupa sehingga terdapat penanggung jawab untuk setiap kegiatan. Hasil observasi menunjukkan bahwa susunan organisasi Crowde mempunyai pembagian kerja yang jelas yang mengatur arus pekerjaan yang terdiri atas Chief Executive Officer, jajaran Kepala Divisi dan para staf pada masing-masing divisi. Untuk penyebutan divisi di Crowde kerap digunakan istilah "team". Jumlah divisi atau team yang terdapat di Crowde sebanyak 5 (lima) divisi, yakni operasional (operations team), keuangan (financial controller), business develop- 


\section{CROWDFUNDING SEBAGAI AKSES ALTERNATIF PERMODALAN \\ BERBASIS TEKNOLOGI DIGITAL PADA KEGIATAN PERTANIAN \\ Astari Avisha, Anne Charina, Trisna Insan Noor, Gema Wibawa Mukti}

ment, pemasaran (marketing), divisi IT (IT Development) yang masing-masing dikepalai oleh seorang kepala divisi atau manajer. Hingga saat ini Crowde secara keseluruhan memiliki 28 orang staf yang berdedikasi untuk membantu petani melalui semangat dan visi misi Crowde. Namun berdasarkan hasil observasi yang dilakukan peneliti, hanya tiga divisi yang berperan pokok dalam pelaksanaan model crowdfunding ini, yaitu tim operations, marketing, dan finance.

Tugas tim operations yang pertama, yaitu mencari dan mengedukasi para petani tentang akses permodalan kegiatan pertanian melalui sistem crowdfunding. Kedua, memastikan projek yang sedang dijalankan oleh petani berjalan dengan lancar dengan melakukan pemantauan dan penindaklanjutan langsung kepada petani secara berkala. Ketiga, mengembangkan produk-produk layanan yang dapat memenuhi kebutuhan petani dengan melakukan identifikasi atas kebutuhan dan minat petani.

Divisi pemasaran (marketing) Crowde merupakan divisi yang berhubungan dengan lingkup eksternal perusahaan. Dalam hal ini tanggung jawabnya termasuk pada aktivitas promosi dalam rangka membangun citra perusahaan untuk menarik pemodal agar tertarik untuk memberikan modal kepada petani yang akan menjalankan proyek pertanian. Melalui tim pemasaran pula proyek pertanian yang akan dijalankan oleh petani mendapatkan modal yakni dengan sejumlah dana yang diberikan oleh para pemodal.

Crowde memiliki divisi keuangan (financial controller) yang merupakan divisi khusus untuk mengatur keuangan internal perusahaan, termasuk untuk mengatur pemasukan dan pengeluaran perusahaan. Sedangkan dalam pelaksanaan model crowdfunding, tugas dari financial controller adalah melakukan disbursement atau pembayaran kepada petani dan juga kepada pemodal. Tim finance juga melakukan pencatatan terhadap nilai-nilai pada proyek yang akan dijalankan petani yang mencakup perhitungan proyeksi keuntungan usahatani, serta persentase bagi hasil dari keuntungan yang nantinya akan diberikan kepada pemodal.

\subsection{Penggerakan/Pelaksanaan (Actu- ating)}

Tahap pelaksanaan merupakan eksekusi dari semua perencanaan yang telah dibuat dengan dukungan pengalokasian tenaga pelaksana (staf) yang terkait dengan model crowdfunding yang dijalankan sebagai akses 
permodalan petani. Berdasarkan hasil pengamatan terhadap objek penelitian, penulis menggolongkan beberapa rangkaian kegiatan yang termasuk ke dalam proses pelaksanaan model crowdfunding Crowde:

\section{a. Penggalangan dana terhadap proyek petani melalui website}

Pada proses penggalangan dana untuk pembiayaan proyek petani, pihak Crowde melakukan analisis proyek terlebih dahulu untuk mengetahui prospek proyek petani tersebut. Tahap analisis dilihat dari kelayakan rencana usahatani, pendapatan, dan proyeksi keuntungan. Selain itu, pada tahap analisis juga mempertimbangkan keadaan lain yang berkaitan dengan usahatani tersebut seperti toko pertanian, offtaker, pasar, dan keadaan pasar komoditas ketika masa panen. Setelah dilakukan analisis proyek tersebut akan terjadi dua kemungkinan, yaitu yang pertama proyek tersebut di pending/hold (jika tidak memenuhi hasil analisa), lalu yang kedua dibuatkan prospektus yang berisi persentase proyeksi keuntungan, tingkat risiko, dan perhitungan prediksi pengembalian kepada pemodal. Setelah proyek tersebut dibuatkan prospektus, maka proyek dapat diunggah di website crowdfunding (www.crowde.co) selama masa penggalangan dana. Adapun periode penggalangan dana di website adalah selama 14 hari. Apabila dalam 14 hari dana yang didapatkan belum mencapai target yang dibutuhkan, maka keputusan selanjutnya diberikan kepada pihak petani untuk memilih mencairkan dana tersebut atau tidak melakukan pencairan dana sama sekali. Akan tetapi, jika kebutuhan dana proyek telah terpenuhi, maka pihak Crowde akan memberikan kontrak kepada petani sebelum melakukan pencairan dana. Kontrak tersebut berisi perjanjian yang menyatakan bahwa pihak petani harus mengembalikan dana tersebut sesuai dengan aturan yang sudah ditetapkan.

\section{b. Penyaluran modal ke petani}

Crowde saat ini menerapkan sistem penyaluran permodalan berupa pemesanan sekaligus pembayaran sarana produksi yang dibutuhkan petani melalui toko pertanian terdekat sehingga petani akan langsung menerima barang-barang input produksi tersebut. Dimana pada awalnya pihak Crowde memberikan pendanaan secara langsung kepada petani berupa dana tunai sejumlah modal yang dibutuhkan. Namun oleh kebanyakan petani, dana tersebut tidak digunakan untuk proses produksi melainkan untuk pemenuhan biaya atau kebutuhan seharihari sehingga menyebabkan produksi 
tidak maksimal serta munculnya isu dari petani seperti gagal panen dan kualitas tanaman buruk setelah beberapa bulan proyek berjalan. ${ }^{3}$ Sistem penyaluran modal berupa pembelian sarana produksi ini merupakan salah satu bentuk pengendalian resiko yang dilakukan oleh pihak Crowde. Petani yang mengajukan permodalan untuk proyek pertaniannya akan menerima sarana produksi sesuai dengan kebutuhan produksi sehingga petani dapat menggunakannya untuk keperluan produksi. Hal ini dilakukan oleh pihak Crowde untuk meminimalisir penggunaan dana permodalan yang tidak sesuai dengan perencanaan proyek.

\section{c. Proses produksi (proyek berjalan)}

Petani dapat memulai produksi setelah menerima input produksi yang telah disalurkan oleh pihak Crowde melalui toko pertanian. Petani diwajibkan untuk dapat mengerjakan proyek sesuai dengan waktu yang sudah ditentukan dan disepakati dengan pihak Crowde sebelumnya. Adapun lama proyek yang dikerjakan oleh petani Crowde hingga proyek selesai paling cepat yaitu selama satu bulan, sedangkan paling lama selama empat sampai enam bulan. Pihak Crowde sejauh ini hanya menerima proyek yang memiliki jangka waktu produksi tidak

\footnotetext{
${ }^{3}$ Hilda, Tim Operasional Crowde
}

lebih dari satu tahun disesuaikan dengan kebutuhan dan minat pemodal dalam menginvestasikan modalnya.

Jika waktu panen tiba, para offtaker petani yang sudah terdaftar di Crowde akan membeli hasil panen tersebut. Offtaker merupakan penadah, ritel, dan penjual hasil panen para petani mitra yang terdaftar oleh pihak Crowde. Setelah produk terjual, lalu keuntungan yang didapat dibagi $60 \%$ untuk pihak petani dan $40 \%$ sisanya diberikan kepada pemodal melalui pihak Crowde.

\section{d. Disbursement}

Sistem pengembalian dana permodalan kepada para pemodal yang dilakukan oleh pihak Crowde yaitu melalui fitur Wallet. Wallet merupakan dompet elektronik yang menyimpan dana permodalan maupun keuntungan (profit) permodalan setelah proyek permodalan selesai. Fitur ini berada di dalam setiap tampilan akun milik pemodal yang terdapat pada website Crowde, sehingga pemodal dapat melihat secara langsung jumlah dana yang telah dikembalikan oleh pihak Crowde. Dana permodalan yang tersimpan di dalam wallet dapat ditarik (withdrawal) ataupun digunakan untuk memodali kembali proyek pertanian lainnya.

"Sistem pengembalian modal sekarang kita ada yang namanya Wallet System, 
jadi saat petani sudah panen atau proyek sudah mendapat hasilnya, sistemnya adalah jumlah keuntungan yang didapatkan pemodal akan masuk ke balance pemodal, jadi pemodal dapat langsung cek nilai atau jumlahnya di website, semacam saldo ATM, dan pemodal bisa melakukan withdraw kalau ingin menarik jumlah dana tersebut dengan request withdraw langsung ",

Untuk dapat membuka Wallet maupun memberikan dana permodalan maka pemodal terlebih dahulu harus mendaftar sebagai pemodal Crowde melalui laman https://crowde.co/register. Sistem pengembalian dan penyimpanan dana permodalan yang digunakan oleh pihak Crowde melalui dompet elektronik atau $e$-wallet seperti ini merupakan salah satu bentuk dari financial technology dimana hal tersebut merupakan inovasi pada sistem penyimpanan dan pembayaran secara digital.

\subsection{Pengawasan (Controlling)}

Proses pengawasan yang terdapat di dalam manajemen model crowdfunding Crowde pada dasarnya merupakan kegiatan yang berjalan beriringan dengan proses berjalannya proyek pertanian yang dijalankan petani. Pihak Crowde sebagai platform crowdfunding sudah seharusnya mempunyai bentuk strategi guna menghadapi risiko kegagalan usaha dan

\footnotetext{
${ }^{4}$ Irfan, Financial Controller
}

kerugian proyek secara tidak langsung, karena pada kenyataannya usaha di bidang pertanian memiliki risiko yang sangat banyak karena berhubungan dengan makhluk hidup. Hal ini juga berhubungan dengan adanya dana yang diinvestasikan oleh para pemodal dalam usaha tersebut.

Beberapa risiko yang dapat terjadi tidak dapat secara langsung dihilangkan walaupun petani peminjam yang bekerjasama dengan Crowde merupakan petani yang telah diseleksi terlebih dahulu oleh pihak Crowde. Bentuk pengendalian risiko yang dilakukan oleh pihak Crowde yaitu dengan membentuk Paguyuban Pejuang Crowde yang dikepalai oleh seseorang yang dianggap sebagai key leader pada sekelompok petani mitra Crowde di suatu daerah.

Paguyuban Pejuang Crowde merupakan wadah bagi para petani untuk saling berbagi informasi (sharing) dimana paguyuban pejuang juga melakukan pendataan serta pelatihan untuk petani mitra Crowde terkait budidaya, financial dan leadership, serta cara membuat laporan atau reporting. Selain itu, pada tahap pengawasan ini pula pihak Crowde mempunyai agent atau orang yang dipercayakan untuk mengawasi serta membantu para petani 
untuk memberikan laporan, dikarenakan petani diwajibkan memberikan laporan terkait perkembangan proyek yang sedang berjalan secara berkala, sementara laporan proyek yang dimaksud berupa laporan singkat. Pemantauan terhadap perkembangan proyek petani ini dilakukan oleh pihak Crowde dalam dua minggu sampai satu bulan sekali. Dengan demikian metode pengawasan yang dimiliki oleh pihak Crowde yakni melalui Paguyuban Pejuang dan agent Crowde menjadikan proses pengawasan berjalan dengan baik dan menjadi keunikan tersendiri dalam manajemen model crowdfunding yang dilakukan oleh Crowde.

\section{Respon Petani dan MitraTerhadap Model Crowdfunding Crowde}

\subsection{Pembahasan Respon}

\section{a. Respon Kognitif}

Respon yang diteliti pada aspek kognitif ini yaitu pengetahuan petani dan mitra terhadap proses atau prosedur dari skema model crowdfunding Crowde. Dari hasil pemaparan jawaban informan didapat sebanyak 4 dari 5 informan menyatakan bahwa proses atau prosedur dari skema model crowdfunding yang diterapkan oleh pihak Crowde sangat mudah untuk diikuti. Sedangkan sebanyak 1 informan lainnya menjawab cukup mudah. Sebagian besar informan tersebut mengetahui dengan jelas skema permodalan Crowde dan prosedur yang harus dipenuhi karena prosesnya yang sederhana dan tidak banyak tahapan sehingga memudahkan proses pengajuan.

Usia petani informan yang menjawab proses maupun prosedur pada model crowdfunding Crowde untuk permodalan ini sangat mudah berada pada rentang usia 22-40 tahun, sedangkan petani informan yang menjawab cukup mudah merupakan petani yang berusia pada rentang 40-48 tahun. Sehingga dapat disimpulkan bahwa terdapat perbedaan respon pada segi pengetahuan dalam mengikuti prosedur skema permodalan melalui model crowdfunding yang didasari oleh tingkat usia. Namun secara keseluruhan petani informan memiliki respon kognitif atau pengetahuan yang positif mengenai skema permodalan Crowde tersebut.

Seluruh informan atau sebanyak $100 \%$ mengetahui tentang adanya skema crowdfunding Crowde sebagai akses permodalan ini dari orang lain. Seluruh informan tersebut menjawab bahwa mereka mengetahui Crowde dari rekan kerja yang sudah lebih dahulu menggunakan skema crowdfunding untuk proyek pertaniannya serta dari teman atau 
relasi yang telah mengetahui tentang akses alternatif permodalan ini. Dari seluruh informan tidak ada yang mengetahui tentang Crowde dari pihak Crowde secara langsung seperti kegiatan seminar atau workshop.

\section{b. Respon Afektif}

Respon afektif dalam penelitian ini yaitu mengenai sikap dan penilaian informan. Item pertanyaan yang diberikan yaitu mengenai penilaian serta tanggapan tentang model crowdfunding sebagai akses permodalan kegiatan pertanian. Jawaban informan menunjukan bahwa sebanyak 3 dari 5 informan menilai model crowdfunding ini sangat bermanfaat, dan 2 lainnya menilai hal tersebut bermanfaat untuk akses permodalan proyek pertanian mereka. Menurut jawaban dari keseluruhan informan, penilaian tersebut dilihat berdasarkan posisi dan kondisi dari informan dalam membutuhkan modal bagi proyek atau kegiatan usahataninya,

Ketiga informan yang menilai bahwa skema crowdfunding ini sangat bermanfaat merupakan informan yang pada saat tertentu dapat sangat membutuhkan modal namun kekurangan dana. Sedangkan kedua informan yang menjawab bermanfaat yaitu informan yang pada saat tertentu telah mempunyai dana sendiri untuk modal proyeknya. Semua informan memberikan tanggapan bahwa model crowdfunding cocok sebagai akses permodalan usaha atau proyek pertanian mereka dengan alasan skema yang digunakan pada model crowdfunding terbilang mudah. Dengan demikian dari jawaban petani informan secara keseluruhan pada aspek afektif menunjukan respon yang positif karena sebagian besar informan menilai model crowdfunding ini sangat bemanfaat dan cocok sebagai akses permodalan usaha atau proyek pertanian mereka.

\section{c. Respon Konatif}

Respon konatif dalam penelitian ini menilai perilaku nyata berupa perbuatan dan tindakan informan sebelum dan sesudah bermitra dengan Crowde untuk mengakses permodalan melalui skema crowdfunding. Hasil penelitian menunjukan bahwa 1 dari 5 orang informan dalam penelitian ini tidak membuat perencanaan usaha yang mencakup rancangan anggaran biaya secara tertulis sebelum melakukan usaha atau proyek pertanian. Informan tersebut mengaku dapat menghitung segala macam perhitungan di luar kepala sehingga tidak perlu mencatat segala kebutuhan biaya sampai perkiraan pendapatan secara rinci di atas kertas. Adapun informan yang 


\section{CROWDFUNDING SEBAGAI AKSES ALTERNATIF PERMODALAN \\ BERBASIS TEKNOLOGI DIGITAL PADA KEGIATAN PERTANIAN \\ Astari Avisha, Anne Charina, Trisna Insan Noor, Gema Wibawa Mukti}

tidak membuat rencana usaha tersebut yaitu petani perseorangan berusia 48 tahun. Sedangkan alasannya yaitu informan tersebut sudah cukup berpengalaman dalam usahatani sehingga hanya membuat perencanaan usaha berupa perkiraan saja. Satu orang informan menyatakan kadang-kadang membuat perencanaan usaha. Petani tersebut merupakan petani perseorangan berusia 40 tahun. Namun kebanyakan petani dan mitra yang dijadikan informan yakni 3 orang selalu membuat perencanaan usaha bahkan sebelum bermitra dengan Crowde karena rencana usaha tersebut masih dianggap sangat penting dalam melakukan kegiatan usaha atau proyek pertanian mereka. Ketiga informan yang selalu membuat perencanaan usaha secara tertulis tersebut berusia di bawah 25 tahun. Dengan demikian hal tersebut menunjukan adanya hubungan antara tingkat usia informan dengan kesadaran atas sikap dan perilaku dalam menjalankan usaha. Semakin muda usia informan maka semakin memiliki kesadaran akan pentingnya membuat perencanaan anggaran biaya usaha demi keberhasilan usaha.

Apabila dilihat dari jumlah hutang yang dimiliki informan setelah bermitra dengan Crowde, jawaban yang didapatkan cukup beragam. Dari 5 orang informan, 3 diantarnya mengatakan bahwa jumlah hutang mereka menurun, sedangkan 2 lainnya mengatakan bahwa setelah bermitra dengan Crowde jumlah hutang yang dimiliki justru meningkat. Adapun ketiga orang informan yang tingkat hutangnya menurun tersebut merupakan petani yang jenis proyeknya berupa budidaya komoditas dan menggunakan skema bagi hasil dimana penyaluran modalnya berupa pembelian sarana produksi yang dibayarkan oleh pihak Crowde. Sementara itu, kedua informan yang menjawab jumlah hutang mereka meningkat merupakan mitra Crowde yang menjalankan proyek berupa perdagangan (trading) dan memiliki kerjasama dengan pihak Crowde menggunakan skema pinjaman.

Pada respon dari segi konatif ini peneliti juga melihat bagaimana tingkat produksi serta keuntungan yang didapatkan informan setelah bermitra dengan Crowde dalam mengakses permodalan. Berdasarkan jawaban dari informan, didapat sebagian besar informan yakni 3 orang menyatakan bahwa mereka memperoleh kenaikan atau tambahan produksi sebesar $25-50 \%$ setelah bermitra dengan Crowde. 
Diantara ketiga orang informan tersebut dua diantaranya merupakan petani yang jenis proyeknya berupa budidaya komoditas dan menggunakan skema permodalan bagi hasil, sedangkan 1 lainnya merupakan mitra Crowde yang proyeknya berupa perdagangan dengan skema pinjaman. Sementara itu, 2 orang informan lainnnya menyatakan bahwa mereka memperoleh tambahan produksi sebesar 50-100\% dari sebelumnya. Kedua informan tersebut merupakan 1 petani dan 1 mitra Crowde yang jenis proyeknya masing-masing berupa budidaya dan jual beli komoditas dengan skema masingmasing adalah bagi hasil dan pinjaman. Dilihat berdasarkan adanya penambahan tingkat produksi, dapat diasumsikan bahwa petani yang mengajukan permodalan untuk jenis proyek budidaya maka diproyeksikan akan memperoleh kenaikan atau tambahan produksi karena sarana produksi (bibit, pupuk, pestisida, dan lainnya) yang telah dibelikan oleh pihak Crowde adalah yang berkualitas dan tepat guna serta sesuai dengan kebutuhan.

Apabila dilihat dari segi keuntungan yang diperoleh informan setelah bermitra dengan Crowde dalam mengakses permodalan, sebanyak 2 orang informan mengatakan bahwa dengan skema crowdfunding ini menambah keuntungan 50-100\% pada usaha mereka, sementara 2 lainnya mengatakan dengan skema crowdfunding menambah keuntungan pada usaha mereka sebanyak $25-50 \%$ dan di bawah $25 \%$. Lebih jelasnya, kedua informan yang memperoleh penambahan keuntungan sebesar 50-100\% tersebut merupakan petani yang jenis proyeknya adalah budidaya dengan skema bagi hasil, dimana kedua informan tersebut melakukan perluasan usaha dan proyek sehingga hasil akhir keseluruhan dari usaha dapat menghasilkan keuntungan hingga tiga kali lipat. Mengenai alasan yang dimiliki informan dalam mengajukan permodalan ke Crowde, yakni sebanyak 4 orang informan menjawab proses pengajuannya mudah dan 1 lainnya menjawab karena melihat model crowdfunding ini dapat melengkapi apabila kekurangan modal. Namun tidak ada satupun informan yang mengajukan permodalan ke Crowde karena adanya promosi dari pihak Crowde.

\subsection{Hasil Respon Keseluruhan}

Berdasarkan hasil respon terhadap ketiga aspek, yaitu kognitif, afektif, dan konatif dari masing-masing informan, maka secara keseluruhan respon petani 
dan mitra menunjukan sebuah keterkaitan dalam membentuk respon yang positif terhadap sistem atau skema crowdfunding sebagai akses permodalan yang dilakukan oleh Crowde. Mengenai aspek kognitif sebagian besar informan menyatakan bahwa proses atau prosedur dari skema model crowdfunding yang diterapkan oleh pihak Crowde sangat mudah untuk diikuti karena prosedur yang harus dipenuhi tersebut sederhana dan tidak banyak tahapan sehingga memudahkan proses pengajuan permodalan. Item pertanyaan pada aspek afektif yakni penilaian dan tanggapan tentang model crowdfunding sebagai akses permodalan kegiatan pertanian menunjukan respon positif yang berarti sebagian besar petani informan menilai bahwa model crowdfunding sangat bermanfaat sementara model crowdfunding dirasa cocok sebagai akses permodalan usaha atau proyek pertanian oleh semua informan karena skema yang digunakan pada model crowdfunding terbilang mudah. Respon informan mengenai item pertanyaan pada aspek konatif bersifat positif karena menunjukan bahwa sebagian besar informan memperoleh tambahan keuntungan pada usaha atau proyek pertaniannya dan sebagian besar petani informan beralasan bahwa mengajukan permodalan ke Crowde karena prosesnya yang mudah.

\section{KESIMPULAN DAN SARAN}

\section{Kesimpulan}

Pada tahap perencanaan (planning), Crowde menetapkan biaya provisi sebesar 3\% bagi setiap proyek bagi hasil yang terdanai oleh pemodal, menetapkan syarat dan ketentuan (kebijakan), melakukan profiling petani, dan project analysis. Dalam pengorganisasian (organizing), divisi yang terlibat langsung dalam proses crowdfunding yaitu operations, finance, dan marketing. Tahap pelaksanaan (Actuating) yang dilakukan oleh Crowde meliputi penggalangan dana terhadap proyek petani melalui website, penyaluran modal ke petani melalui toko tani, proses produksi (proyek berjalan), dan pengembalian dana pemodal menggunakan fitur Wallet. Sedangkan proses pengawasan (controlling) dalam manajemen crowdfunding Crowde berjalan beriringan dengan proses berjalannya proyek pertanian yang dijalankan petani yaitu berupa pemantauan yang dilakukan pihak Crowde menggunakan sistem pelaporan proyek.

Respon petani mitra Crowde menunjukan respon yang positif terhadap 
skema crowdfunding sebagai akses permodalan. Hampir semua petani mitra mengatakan proses atau prosedur dari skema permodalan tersebut sangat mudah diikuti. Sebagian besar petani menilai bahwa model crowdfunding ini sangat bermanfaat dan cocok sebagai akses permodalan petani. Selain itu, alasan sebagian besar petani bermitra dengan Crowde yaitu karena proses pengajuan pada skema crowdfunding yang terbilang mudah.

\section{Saran}

Tahap perencanaan dan pengawasan yang dilakukan oleh pihak Crowde, baik terhadap petani maupun proyek yang sedang berjalan, sudah cukup baik. Namun mengingat adanya sejumlah risiko yang dihadapi dalam proyek atau usaha pertanian, maka Crowde sebagai pelaku Fintech yang menyediakan layanan peer to peer lending perlu bekerjasama dengan asuransi pertanian sebagai bentuk antisipasi untuk meminimalisasi kerugian petani jika terjadi gagal panen.

Perlu adanya divisi atau pelaksana Research and Development (R\&D) di dalam manajerial Crowde sebagai unit kerja yang secara khusus bertujuan untuk mengembangkan produk atau proses baru maupun meningkatkan produk atau proses yang ada. R\&D harus dikoordinasikan untuk memastikan bahwa perusahaan menyediakan apa yang diinginkan pelanggan yang mana dalam hal ini adalah petani dan pemodal, dengan cara yang paling efisien, efektif, dan ekonomis. Dengan adanya R\&D maka dapat pula dilakukan penelitian lebih mendalam terkait perilaku serta kebutuhan petani yang dapat dijadikan acuan dalam pengembangan skema pada model crowdfunding yang dilakukan.

Perlu dilakukan penelitian lebih lanjut mengenai respon dan persepsi petani terkait pengaruh model crowdfunding terhadap perilaku dan tingkat ekonomi petani agar dapat dijadikan bahan masukan dan pertimbangan untuk pengembangan platform crowdfunding di sektor pertanian yang ada di Indonesia.

\section{DAFTAR PUSTAKA}

Alt, R., \& Puschmann, T. 2012. The Rise of Customer-Oriented Banking Electronic Markets are Paving the Way. Electronic Markets.

Arner, D. W., Barberis, J., \& Buckley, R. P.2015. The evolution of Fintech: A new post-crisis paradigm. Geo. J. Int'l L., 47, 1271.

Asosiasi Penyelenggara Jasa Internet Indonesia. 2016. Penetrasi \& Perilaku Pengguna Internet Indonesia. Daily Social. 2017. 
Fintech Report 2017. https://dailysocial.id/report/post/fint ech-report-2017\#

Azwar, A. 1996. Pengantar Administrasi Kesehatan. Jakarta: Binarupa. Aksara.

Azwar, S. 1995. Sikap Manusia. Edisi kedua.Yogyakarta: Pustaka Pelajar.

Barrette, E. 2011. Crowdfunding: A communal business model. Communities, 152, 32-35.

Belleflamme, P., Omrani, N., \& Peitz, M. (2016). Understanding the strategies of crowdfunding platforms. CESifo DICE Report.

Handoko, T.H. 2000. Dasar Dasar Manajemen Produksi dan Operasi, Edisi II. Yogyakarta: BPFE.

Iman, N. 2016. Financial Technology dan Lembaga Keuangan.

Yogyakarta.

http://nofieiman.com/wpcontent/images/financialtechnology-lembaga-keuangan.pdf

Koontz, H. 2010. Essentials of Management. McGraw-Hill Education.

Micu, I., \& Micu, A. 2016. Financial Technology (Fintech) and Its Implementation on The Romanian Non-Banking Capital Market. SEAPractical Application of Science, 11, 379-384.
Mollick, E. 2014. The Dynamics of Crowdfunding: An Exploratory Study. Journal of Business Venturing 2(1): 1-16.

Otoritas Jasa Keuangan. 2017. Financial Technology (FinTech) di Indonesia. Jakarta.

http://www.ibs.ac.id/img/doc/MDH $\% 20 \% 20$ FinTech\%20IBS\%20June $\% 202017 . p d f$

Siswanto, H.B. 2006. Pengantar Manajemen. Jakarta: Bumi Aksara.

Soetriono, S., Suwandari, A., \& Rijanto, R. 2006. Pengantar Ilmu Pertanian (Agraris, Agrobisnis, dan Industri). Jakarta: Gramedia.

Subyantoro, A. \& Suwarto, FX. 2017. Metode \& Teknik Penelitian Sosial. Yogyakarta: ANDI.

Sugiyono. 2012. Metode Penelitian Kuantitatif Kualitatif dan RND. Bandung: Alfabeta.

Supanggih, D., \& Widodo, S. 2013. Aksesibilitas Petani Terhadap Lembaga Keuangan (Studi Kasus Pada Petani di Desa Sidodadi Kecamatan Sukosewu Kabupaten Bojonegoro). Agriekonomika 2(2): 163-173. 